\title{
Tectonic and climatic controls on the Chuquibamba landslide (western Andes, southern Peru)
}

\author{
A. Margirier ${ }^{1}$, L. Audin ${ }^{1,2}$, J. Carcaillet ${ }^{1}$, S. Schwartz ${ }^{1}$, and C. Benavente ${ }^{3}$ \\ ${ }^{1}$ Institut des Sciences de la Terre, Université Grenoble I, CNRS, 1381 rue de la Piscine, \\ 38400 Grenoble CEDEX 09, France \\ ${ }^{2}$ Institut de recherche pour le développement, Institut des Sciences de la Terre, 1381 rue de la Piscine, \\ 38400 Grenoble CEDEX 09, France \\ ${ }^{3}$ Instituto Geológico Minero y Metalúrgico, A. Canadà 1470, San Borja, Lima, Peru \\ Correspondence to: A. Margirier (audrey.margirier@ujf-grenoble.fr)
}

Received: 23 October 2014 - Published in Earth Surf. Dynam. Discuss.: 15 December 2014

Revised: 11 May 2015 - Accepted: 01 June 2015 - Published: 25 June 2015

\begin{abstract}
The contribution of landslides to the Quaternary evolution of relief is poorly documented in arid contexts. In southern Peru and northern Chile, several massive landslides disrupt the arid western Andean front. The Chuquibamba landslide, located in southern Peru, belongs to this set of large landslides. In this area, the Incapuquio fault system captures the intermittent drainage network and localizes rotational landslides. Seismic activity is significant in this region with recurrent $M_{\mathrm{w}} 9$ subduction earthquakes; however, none of the latest seismic events have triggered a major landslide. New terrestrial cosmogenic dating of the Chuquibamba landslide provides evidence that the last major gravitational mobilization of these rotational landslide deposits occurred at $\sim 102 \mathrm{ka}$, during the Ouki wet climatic event identified on the Altiplano between 120 and $98 \mathrm{ka}$. Our results suggest that wet events in the arid and fractured context of the Andean forearc induced these giant debris flows. Finally, our study highlights the role of tectonics and climate on (i) the localization of large Andean landslides in the Western Cordillera and on (ii) the long-term mass transfer to the trench along the arid Andean front.
\end{abstract}

\section{Introduction}

In active mountain ranges, landslides are an important process in long-term erosion and thus contribute to the geomorphologic evolution of relief (Korup et al., 2007). Despite their importance in terms of hazards, landslide maps remain rare (Guzzetti et al., 2012) and information on the type, age or distribution of individual landslides is often lacking. Only a few publications deal with landslide triggering and/or evolution in arid contexts such as the western Andean flank, where several gigantic scarps disrupt the forearc piedmont (Audin and Bechir, 2006; Pinto et al., 2008; Strasser and Schlunegger, 2005; Wörner et al., 2002; Mather et al., 2014; Crosta et al., 2015). In contrast, because of the potential seismotectonic trigger (Keefer, 1984, 2002; McPhillips et al., 2014), landslide triggering along subduction active margins has been studied for a number of years, but most previous studies focused on humid climatic settings (Taiwan, New
Zealand, Papua New Guinea, Japan; Meunier et al., 2008; Hovius et al., 2011). In southern Peru, the topographic gradient (average slope of $4 \%$ between the coast and the Western Cordillera), the crustal seismotectonic activity and the aridity of the forearc region has been directly linked to Andean uplift and subduction of the Nazca Plate for the last $25 \mathrm{Myr}$ at least (Devlin et al., 2012; Alpers and Brimhall, 1988; Dunai et al., 2005). However, Quaternary tectonic crustal activity and its role in the localization of landslides along the Western Andean Escarpment has never been explored in southern Peru and northern Chile. As a consequence, numerous questions remain concerning the importance of giant landslides in slope erosion relative to other nonseismic agents of erosion such as climatic forcing.

The "Chuquibamba landslide" is a large complex zone of imbricated landslides (about $80 \mathrm{~km}^{2}$ ) affecting the western Andean Cordillera in southern Peru. It belongs to the Andean 


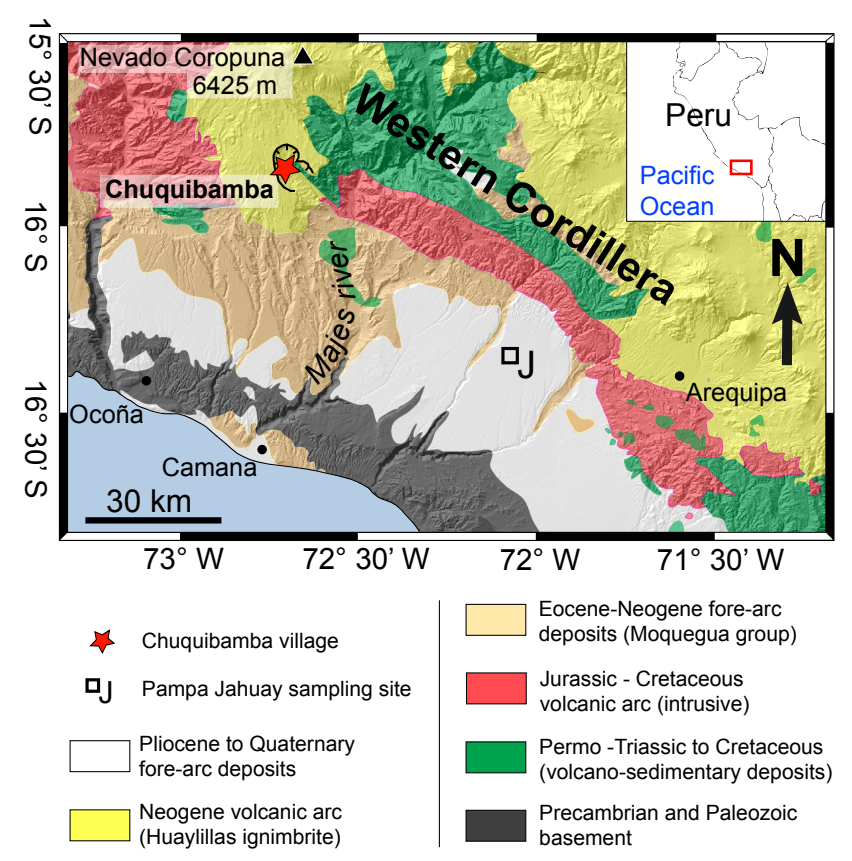

Figure 1. Simplified geological map of South Peru (modified from Roperch et al., 2006; INGEMMET, 2001), showing the village of Chuquibamba (red star), the destabilization zone and the Pampa Jahuay sampling site (J). Coordinates are given in WGS 84 longitude and latitude (degrees). Inset shows the study area location within Peru and a part of South America.

arid piedmont, where geomorphic markers are minimally affected by erosion/transport processes (Hall et al., 2008). In this study, we aim to explore how seismotectonic activity and/or abrupt climate change may potentially have triggered the large Chuquibamba landslides. In this paper, we map out the area and characterize the tectonic and geomorphological settings, use terrestrial cosmogenic nuclides (TCN) to date pertinent markers of the last debris-flow event, and document the evolution of the landslide area.

\section{Context}

\subsection{Geologic and climatic setting of Chuquibamba region}

The Andean Pacific arid front comprises different morphological units: the Coastal Cordillera $0-1000 \mathrm{~m}$ above sea level (a.s.l.), the Pacific piedmont 1000-1500 m a.s.l. and the Western Cordillera 1500-6000 m a.s.l. In southern Peru, the Western Cordillera corresponds to a Jurassic to Cretaceous volcanic arc (Atherton et al., 1985) (Fig. 1). These magmatic and volcano-sedimentary rocks are emplaced within a Precambrian to Paleozoic basement. During the Eocene to Neogene, volcano-sedimentary deposits of the Moquegua group were overlain onto the Western Cordillera. This group is partly covered by the Huaylillas ignimbrite, produced

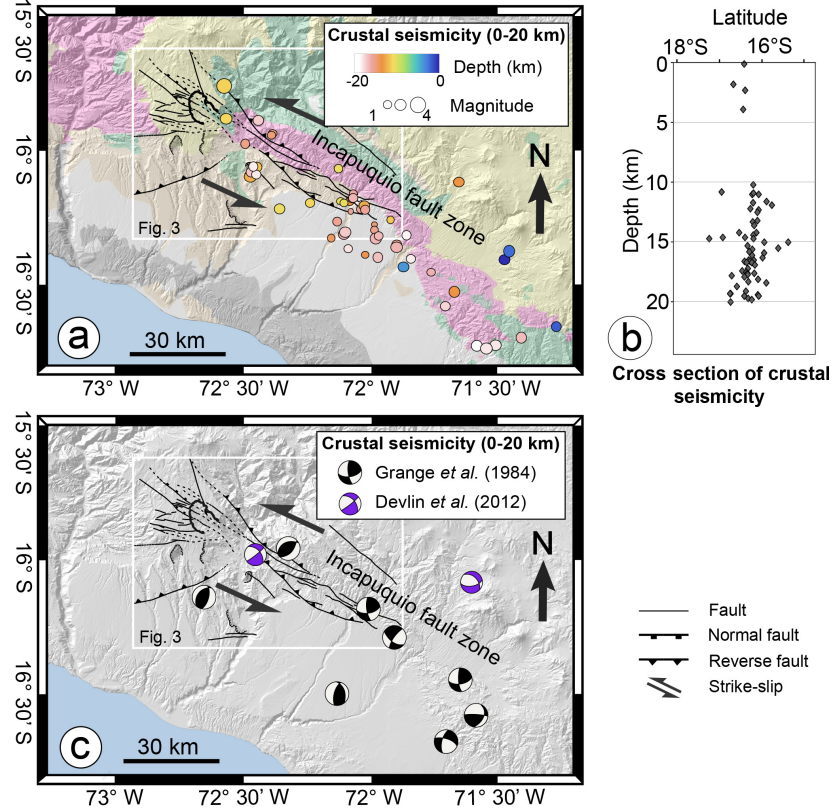

Figure 2. Regional crustal seismicity and focal mechanisms. (a) Crustal seismicity (depth $<20 \mathrm{~km}$ ) and faults are represented on the geological map of South Peru (modified from Roperch et al., 2006; INGEMMET, 2001). (b) Cross section showing the vertical cluster of earthquakes. (c) Focal mechanisms from Grange et al. (1984) and Devlin et al. (2012); the kinematics of the Incapuquio fault system are indicated by black arrows.

during the Neogene volcanism and dated at $14.3-12.7 \mathrm{Ma}$ $\left({ }^{40} \mathrm{Ar} /{ }^{39} \mathrm{Ar}\right.$; Thouret et al., 2007). The top of this ignimbrite forms a weathering surface. The Moquegua group and Huaylillas ignimbrite reach a maximum of $1500 \mathrm{~m}$ thick (Thouret et al., 2007; Gunnell et al., 2010). Some volcanosedimentary rocks were deposited on the coastal plains during the late Neogene. Starting at $\sim 9-10 \mathrm{Ma}$, these units were incised by $1-3 \mathrm{~km}$ deep canyons that strike perpendicular to NW-SE-striking range (Schildgen et al., 2007, 2009; Thouret et al., 2007; Gunnell et al., 2010).

The Western Cordillera and Pacific piedmont are affected by Quaternary tectonic deformation mainly expressed in the Western Cordillera by an active fault system striking parallel to the range (Sébrier et al., 1985; Hall et al., 2008, 2012) (Fig. 2). Along the Andes, the active subduction and induced crustal deformation largely control the geomorphologic evolution of the forearc (Keefer, 1994; Keefer and Moseley, 2004; Audin et al., 2006; Tavera et al., 2007; Perfettini et al., 2010). The piedmont region is exposed to extremely low denudation rates ranging from $0.1-1 \mathrm{~mm} \mathrm{kyr}^{-1}$ in the coastal desert and Pacific piedmont to $1-46 \mathrm{~mm} \mathrm{kyr}^{-1}$ in the Western Cordillera (values obtained for Quaternary timescale by TCN dating; Hall et al., 2008; Kober et al., 2007) due to the arid climatic conditions since at least the Neogene (Mortimer, 1980; Alpers and Brimhall, 1988; Dunai et al., 2005; Rech et al., 2006). Moreover, the Altiplano has been the target of 
many paleoclimatic investigations (Thompson et al., 1998, 2000; Cross et al., 2001; Baker et al., 2001; Placzek et al., 2006, 2013) that highlighted climate fluctuations for the last 130 kyr. Steffen et al. (2009, 2010), Carretier et al. (2013) and Bekaddour et al. (2014) highlighted the contribution of these wet climatic events to mass transport in major canyons from the Altiplano to the Pacific coast. In contrast, McPhillips et al. (2014) observed that the landslide frequency appears to have not changed during the Quaternary and thus questioned the impact of the climatic fluctuations on landsliding and erosion rate.

\subsection{Fault geometry and kinematics}

In southern Peru, the Incapuquio fault zone has a strong geomorphic imprint on the Andean range (Huaman, 1985; Sébrier et al., 1985). Based on microtectonic studies, Sébrier et al. $(1985,1988)$ and Schildgen et al. (2009) identified different kinematic episodes. Sébrier et al. $(1985,1988)$ defined major Tertiary and early Quaternary compressional phases and a minor late Quaternary episode of normal faulting. Schildgen et al. (2009) proposed that a Tertiary episode of strike-slip and normal faulting occurred between 14 and 2.2 Ma. However, relocated microseismicity (Grange et al., 1984) and teleseismic data (Devlin et al., 2012) demonstrate present-day reverse and strike-slip components on the Lluta fault segment and more regionally for the Incapuquio fault system in the Arequipa region (Fig. 2). The Neogene surface and Quaternary drainage network are also affected by these fault segments (Fig. 3). Channel orientations and captures evidence a sinistral strike-slip component along an extrado graben (Fig. 3c). These Quaternary offsets and inferred kinematics are consistent with the vertical geometry of the fault plane imaged at depth $(20 \mathrm{~km})$ by the distribution of crustal earthquakes (Fig. 2b) and focal mechanisms (Fig. 2c) $\left(M_{\mathrm{w}}<5 ;<20 \mathrm{~km}\right.$, Grange et al., 1984; Devlin et al., 2012). Local reverse and normal apparent surface movements are known to occur along major strike-slip faults in the forearcs of northern Chile (Victor et al., 2004) and southern Peru (Hall et al., 2012). The present-day main sinistral strike-slip kinematics of the Incapuquio fault system demonstrated by the seismicity is compatible with normal apparent displacements as observed by Schildgen et al. (2009) and Sébrier et al. $(1985,1988)$.

\subsection{Geomorphological setting}

The Chuquibamba landslide is located in the Majes River catchment, along the western flank of the Central Andes, between 1000 and $4000 \mathrm{~m}$ a.s.l. (Fig. 1). The Chuquibamba landslide comprises an imbricated set of rotational landslides, a debris-flow deposit and, in the lower area, a megafan and alluvial terraces (Fig. 3a). Upstream, the rotational landslides remobilize the thick Huaylillas ignimbrite formation fractured by the activity along the Incapuquio fault system.
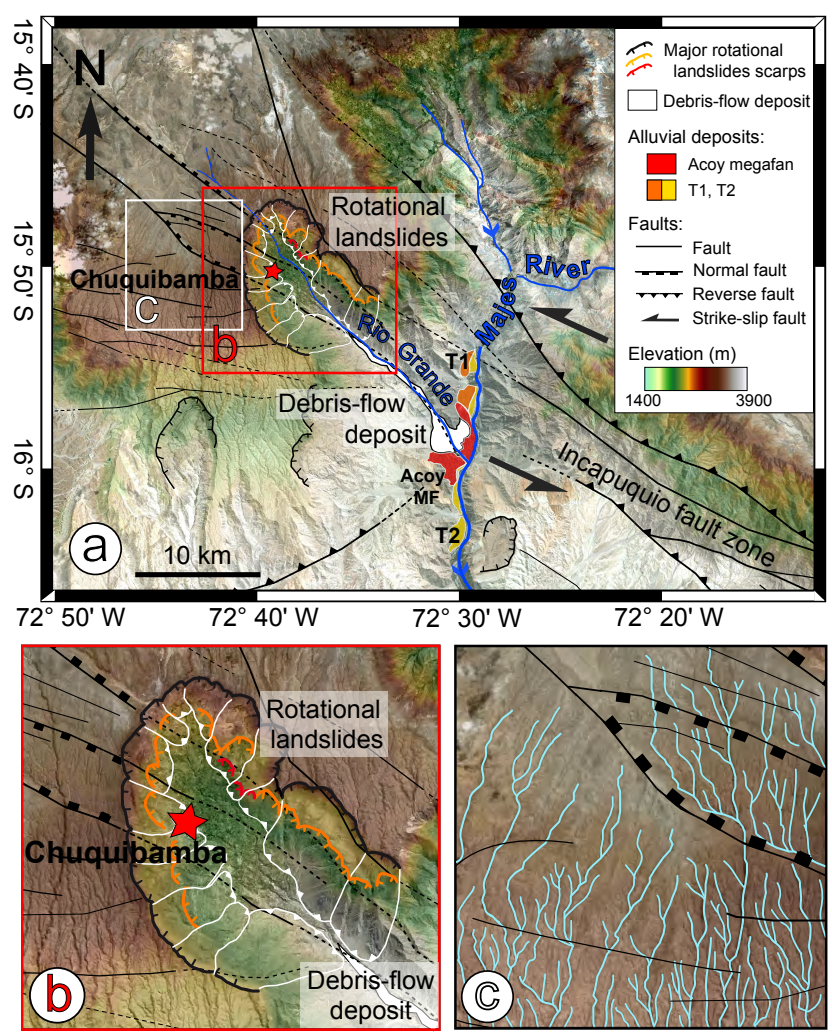

Figure 3. SRTM numerical elevation model overlay by Landsat image of the Chuquibamba destabilization zone. Coordinates are given in WGS 84 longitude and latitude (degrees). (a) Global view of the Chuquibamba area pointing major detachment scarps, debris-flow deposits, Acoy megafan, alluvial terraces and faults. (b) Close-up of the amphitheater-shaped scar of the rotational landslides showing the different head scarps. (c) Drainage network and faults.

We estimate the total volume mobilized for Chuquibamba landslide reaches $\sim 40 \mathrm{~km}^{3}$. These imbricated rotational landslides correspond to a succession of three head scarps (Fig. 3b). The scar of the rotational landslides, cutting the Huaylillas weathering surface, delimits the landslide area (Fig. 3b) and forms an elongated amphitheater trending in the NW-SE direction. This direction does not fit with the overall southwest-dipping topographic slope but rather corresponds to the structural trend of active faults (Fig. 3a). Moreover, several fault planes appear to control the shape of the polylobed rotational landslides (Fig. 3b).

The base of the cirque ( $2900 \mathrm{~m}$ a.s.l.) is formed by smooth, sub-horizontal surfaces (Fig. 3b). These surfaces likely correspond to former lateral landslide deposits re-incised by the river after the initiation of the Chuquibamba landslide.

The debris flow remobilizes the rotational landslide deposits. It consists of mixed angular clasts, breccias and numerous meter-size boulders embedded in a thin volcanic matrix (Fig. 4a), reworked from the Huaylillas ignimbrite. The debris-flow deposit displays a smooth and $100 \mathrm{~m}$ scale undulated surface (Fig. 4a). In its upper part, the debris flow 


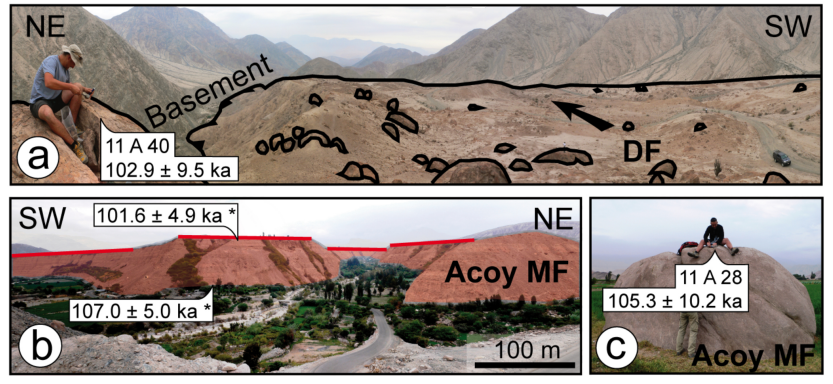

Figure 4. Field photographs showing the debris-flow deposit morphology and the Acoy megafan. (a) Characteristic block sampled on the debris-flow deposit. The arrow indicates flowing direction of the debris flow. (b) General view of the Acoy megafan (Acoy MF); red lines highlight the top of the terrace. The OSL ages obtained by Steffen et al. (2010) for the Acoy megafan are indicated with an asterisk. (c) Block sampled on the megafan.

rests directly on the basement (Fig. $4 \mathrm{a}$ ), but $30 \mathrm{~km}$ downstream of the head scarp, in the vicinity of the Majes River (900 ma.s.l.), the debris flow overlays the Acoy megafan (Fig. 3a).

The megafan, located downstream of the Chuquibamba village at the outlet of the Rio Grande, is about $100 \mathrm{~m}$ thick and $8 \mathrm{~km}$ long (Fig. 3a). Its stratigraphy indicates both a response to multiple phases of sediment production and surface erosion in the Rio Grande and fluvial incision in the Majes Canyon (Steffen et al., 2010). Steffen et al. (2010) described an alternation of sheet flood units and debrisflow deposits, and a typical clast- to matrix-supported fabric. Optically stimulated luminescence (OSL) dating places the Acoy megafan formation between $107.0 \pm 5.0 \mathrm{ka}$ (base) and $101.6 \pm 4.9 \mathrm{ka}$ (top) (Steffen et al., 2010). Two levels of alluvial terraces (T1, T2) have been identified in the Majes canyon in the vicinity of the megafan. The Acoy megafan and alluvial-terrace development has been linked to wetter episodes, identified in paleoclimate proxies from Altiplano paleolake sediments (Placzek et al., 2006, 2013), driving the fluctuations in the Colca/Majes hydrologic regime (Steffen et al., 2010).

\section{Sampling strategy and methods}

The last debris-flow deposit is well preserved all along the Chuquibamba valley (Fig. 3a). Six meter-scale boulders of rhyolite entrapped in the Acoy megafan and debris-flow surfaces (Fig. 4a and c) have been sampled. The preserved surface of the boulders (evidenced by desert varnish) indicates minimal post-abandonment erosion; they are well anchored and sufficiently elevated on the debris-flow surface to minimize the possibility of post-depositional movement and potential covering by surficial material. In order to provide an additional constraint on the regional erosion rate and consequently improve the exposure age determination, we sampled a quartzite pebble from the preserved Pampa Jahuay surface in the pediplains $60 \mathrm{~km}$ southeast of Chuquibamba (Fig. 1, Table 1).

Sample preparation was conducted at the Institut des Sciences de la Terre (ISTerre, Grenoble). As the rhyolitic samples contained enough quartz, we extracted in situ produced beryllium-10 $\left({ }^{10} \mathrm{Be}\right)$ using the chemical procedures developed by Brown et al. (1991) and Merchel and Herpers (1999). The AMS ${ }^{10}$ Be measurements were performed at the ASTER AMS French national facility (CEREGE, Aix en Provence). Analytical uncertainties include uncertainties associated with AMS counting statistics, AMS external error $(1 \%)$, standard reproducibility and chemical blank measurements $\left({ }^{10} \mathrm{Be} /{ }^{9} \mathrm{Be}\right.$ blank $\left.=1.60 \pm 0.72 \times 10^{-15}\right)$. External uncertainties include $6 \%$ uncertainty in the production rate and $8 \%$ uncertainty in the ${ }^{10} \mathrm{Be}$ decay constant. Exposure ages were calculated using the online CRONUS calculator (Balco et al., 2008). Results are computed using the time-dependent scaling scheme of Lal (1991) modified by Stone (2000).

\section{TCN dating}

In the debris-flow deposit and Acoy megafan samples, the ${ }^{10} \mathrm{Be}$ concentrations are relatively consistent and range from $6.67 \pm 0.28 \times 10^{5}$ to $1.38 \pm 0.08 \times 10^{6}$ atoms per gram of quartz (at $\mathrm{g}^{-1} \mathrm{qtz}$ ) (Table 1). The high ${ }^{10} \mathrm{Be}$ content of the sample $\left(1.33 \pm 0.02 \times 10^{7}\right.$ at $\left.\mathrm{g}^{-1} \mathrm{qtz}, 11 \mathrm{~A} 28\right)$ collected from the Pampa Jahuay suggests an extremely low erosion rate lasting at least for the last $2 \mathrm{Myr}$ in the southern Peruvian forearc $(1.9 \pm 0.3 \mathrm{Myr})$. The computed erosion rate $\left(0.21 \pm 0.05 \mathrm{~mm} \mathrm{kyr}^{-1}\right)$ agrees with rates published by Hall et al. (2012) for the South Peru and by Kober et al. (2007) for Chile (Oxaya formation). These results support the hypothesis of an insignificant erosion of the sampled boulders of the debris-flow deposit. TCN exposure ages deduced from debris-flow boulders (with an erosion rate of $0.21 \mathrm{~mm} \mathrm{kyr}^{-1}$ ) range from $96.1 \pm 8.9$ to $108.5 \pm 10.2^{10} \mathrm{Be}-$ ka (Table 1, Fig. 5). Considering the uncertainties, exposure ages are consistent and suggest a single remobilization event with a weighted average age of $101.9 \pm 5.5 \mathrm{ka}$. The age of the large boulder sampled on the Acoy megafan (Fig. 4) is $105.3 \pm 10.2^{10} \mathrm{Be}-\mathrm{ka}$ (Table 1$)$.

\section{Discussion}

\subsection{Tectonic and climatic forcing on Chuquibamba landslide evolution}

The weighted average age of debris-flow boulders indicates a last major debris flow at $101.9 \pm 5.5 \mathrm{ka}$. The abandonment age of the megafan surface $\left(105.3 \pm 10.2^{10} \mathrm{Be}-\mathrm{ka}\right.$; Figs. 4 and 5) agrees with the OSL ages published by Steffen et al. (2010) (i.e., $107.0 \pm 5.0 \mathrm{ka}$ at the base of the megafan and $101.6 \pm 4.9 \mathrm{ka}$ near the top). The Ouki wet event has been 
Table 1. TCN results of the Chuquibamba Valley and the Pampa Jahuay.

\begin{tabular}{|c|c|c|c|c|c|c|c|c|c|c|c|}
\hline \multirow[t]{2}{*}{ Sample } & \multirow[t]{2}{*}{$\begin{array}{l}\text { Latitude } \\
\left({ }^{\circ} \mathrm{N}\right)\end{array}$} & \multirow[t]{2}{*}{$\begin{array}{l}\text { Longitude } \\
\left({ }^{\circ} \mathrm{W}\right)\end{array}$} & \multirow[t]{2}{*}{$\begin{array}{l}\text { Elevation } \\
\text { (ma.s.l.) }\end{array}$} & \multicolumn{2}{|c|}{$\begin{array}{l}\text { Production rate } \\
\left(\text { atoms }^{-1} \mathrm{yr}^{-1}\right)\end{array}$} & \multirow{2}{*}{$\begin{array}{c}\text { Geomorphic } \\
\text { scaling } \\
\text { factor }^{\mathrm{a}}\end{array}$} & \multirow{2}{*}{$\begin{array}{c}\text { Sample } \\
\text { thickness } \\
\text { factor }^{\mathrm{b}}\end{array}$} & \multirow[t]{2}{*}{$\begin{array}{l}\text { Quartz } \\
\text { (g) }\end{array}$} & \multirow[t]{2}{*}{$\begin{array}{l}{ }^{9} \mathrm{Be} \\
(\mathrm{mg})\end{array}$} & \multirow[t]{2}{*}{${ }^{10} \mathrm{Be} /{ }^{9} \mathrm{Be}^{\mathrm{c}}$} & \multirow{2}{*}{$\begin{array}{c}\text { Uncertainty } \\
{ }^{10} \mathrm{Be} /{ }^{9} \mathrm{Be} \\
(\%)\end{array}$} \\
\hline & & & & Spallation & Muons & & & & & & \\
\hline \multicolumn{12}{|l|}{ Blank } \\
\hline BKGRE67 & - & - & - & - & - & - & - & - & 0.486 & $1.604 \times 10^{-15}$ & 44.74 \\
\hline \multicolumn{12}{|c|}{ Debris-flow deposit } \\
\hline $11 \mathrm{~A} 39$ & -15.9294 & -72.5306 & 1315 & 7.15 & 0.27 & 0.99 & 0.98 & 9.54 & 0.291 & $3.998 \times 10^{-13}$ & 3.10 \\
\hline $11 \mathrm{~A} 40$ & -15.5327 & -72.9267 & 1356 & 7.43 & 0.28 & 0.99 & 0.99 & 6.02 & 0.254 & $3.257 \times 10^{-13}$ & 3.16 \\
\hline $11 \mathrm{~A} 41$ & -15.5343 & -72.9245 & 1391 & 7.39 & 0.28 & 0.98 & 0.97 & 5.10 & 0.290 & $2.566 \times 10^{-13}$ & 3.52 \\
\hline $11 \mathrm{~A} 42$ & -15.9145 & -72.5487 & 1543 & 8.40 & 0.29 & 0.99 & 0.98 & 10.98 & 0.292 & $5.468 \times 10^{-13}$ & 3.44 \\
\hline $11 \mathrm{~A} 43$ & -15.8784 & -72.5927 & 1899 & 10.54 & 0.33 & 0.98 & 0.98 & 10.44 & 0.291 & $6.981 \times 10^{-13}$ & 6.14 \\
\hline \multicolumn{12}{|c|}{ Acoy megafan } \\
\hline $11 \mathrm{~A} 28$ & -16.0091 & -72.4892 & 817 & 5.13 & 0.24 & 1.00 & 0.99 & 9.77 & 0.294 & $3.196 \times 10^{-13}$ & 4.18 \\
\hline \multicolumn{12}{|c|}{ Pampa Jahuay } \\
\hline $11 \mathrm{~A} 62$ & -16.3408 & -72.0840 & 1592 & 8.76 & 0.30 & 1.00 & 0.97 & 19.96 & 0.295 & $1.320 \times 10^{-11}$ & 1.71 \\
\hline Sample & $\begin{array}{c}{ }^{10} \mathrm{Be} \\
\text { concentration } \\
\left(\times 10^{3} \text { atoms } \mathrm{g}^{-1}\right. \\
\mathrm{qtz})\end{array}$ & $\begin{array}{c}{ }^{10} \mathrm{Be} \\
\text { concentration } \\
\text { uncertainty } \\
\left(\times 10^{3} \text { atoms } \mathrm{g}^{-1}\right. \\
\mathrm{qtz})\end{array}$ & $\begin{array}{c}\text { Erosion } \\
\text { rate } \\
\left(\mathrm{m} \mathrm{Myr}^{-1}\right)\end{array}$ & $\begin{array}{l}\text { Erosion } \\
\text { rate } \\
\text { external } \\
\text { uncertainty } \\
\left(\mathrm{m} \mathrm{Myr}^{-1}\right)\end{array}$ & $\begin{array}{c}\text { Age }{ }^{10} \mathrm{Be} \\
\quad(\mathrm{kyr}) \\
e=0^{\mathrm{d}}\end{array}$ & $\begin{array}{l}\text { Age }{ }^{10} \mathrm{Be} \\
\text { internal } \\
\text { uncertainty } \\
{(\text { kyr })^{\mathrm{e}}}^{\mathrm{e}}\end{array}$ & $\begin{array}{c}\text { Age }{ }^{10} \mathrm{Be} \\
\text { external } \\
\text { uncertainty } \\
\quad(\mathrm{kyr})^{\mathrm{f}}\end{array}$ & $\begin{array}{c}\text { Age }{ }^{10} \mathrm{Be} \\
(\mathrm{ka}) \\
e=0.21 \\
\mathrm{~m} \mathrm{Myr}^{-1 \mathrm{~d}}\end{array}$ & $\begin{array}{c}\text { Age }{ }^{10} \mathrm{Be} \\
\text { internal } \\
\text { uncertainty } \\
(\mathrm{kyr})^{\mathrm{e}}\end{array}$ & $\begin{array}{l}\text { Age }{ }^{10} \mathrm{Be} \\
\text { external } \\
\text { uncertainty } \\
(\mathrm{kyr})^{\mathrm{f}}\end{array}$ & \\
\hline \multicolumn{12}{|l|}{ Blank } \\
\hline BKGRE67 & 31.374 & 14.036 & - & - & - & - & - & - & - & - & \\
\hline \multicolumn{12}{|c|}{ Debris-flow deposit } \\
\hline $11 \mathrm{~A} 39$ & 828.574 & 25.748 & - & - & 95.99 & 3.67 & 8.83 & 96.11 & 3.68 & 8.86 & \\
\hline $11 \mathrm{~A} 40$ & 938.088 & 29.597 & - & - & 102.72 & 4.07 & 9.49 & 102.86 & 4.09 & 9.52 & \\
\hline $11 \mathrm{~A} 41$ & 992.821 & 34.974 & - & - & 108.29 & 4.85 & 10.17 & 108.46 & 4.87 & 10.2 & \\
\hline $11 \mathrm{~A} 42$ & 992.144 & 34.175 & - & - & 97.51 & 4.17 & 9.10 & 97.88 & 4.19 & 9.15 & \\
\hline $11 \mathrm{~A} 43$ & 1375.656 & 84.507 & - & - & 106.7 & 8.30 & 11.42 & 106.87 & 8.34 & 11.46 & \\
\hline \multicolumn{12}{|c|}{ Acoy megafan } \\
\hline $11 \mathrm{~A} 28$ & 666.607 & 27.905 & - & - & 105.1 & 5.55 & 10.15 & 105.26 & 5.57 & 10.19 & \\
\hline \multicolumn{12}{|c|}{ Pampa Jahuay } \\
\hline $11 \mathrm{~A} 62$ & 13318.936 & 227.531 & 0.21 & 0.05 & 1894.08 & 94.88 & 271.34 & - & - & - & \\
\hline
\end{tabular}

(a) The topographic scaling factor has been calculated following the method of Dunne et al. (1999). (b) The sample thickness correction has been calculated with a 2.7 density factor. (c) AMS (accelerator mass spectrometry) analyses were carried out at the French AMS facility ASTER. Calibration of ${ }^{10}$ Be concentrations were done with NIST standard reference material 4325 , using a ${ }^{10} \mathrm{Be} /{ }^{9} \mathrm{Be}$ ratio of $2.79 \times 10^{-11}$ and a ${ }^{10} \mathrm{Be}$ half-life of $1.387 \pm 0.012 \times 10^{6}$ years (Chmeleff et al., 2010; Korschinek et al., 2010). Results have been corrected from the chemical blank $\left({ }^{10} \mathrm{Be} /{ }^{9} \mathrm{Be}\right.$ blank $\left.=1.60 \pm 0.72 \times 10^{-15}\right)$. Internal uncertainties consider the analytical uncertainties including counting statistics, the instrumental variability (1\%), the standard deviation and chemical blank. External uncertainties include $6 \%$ uncertainty in the production rate and $8 \%$ uncertainty in the ${ }^{10} \mathrm{Be}$ decay constant. (d) Ages have been computed with the CRONUS calculator (Balco et al., 2008) using the time-dependent production rate of Lal (1991) modified by Stone (2000). The production rate calibrate by Kelly et al. (2015) on recent timescale in Peruvian Andes is not relevant for this study. For our range of ages (100 kyr) geomagnetic variations have to be considered. Ages are presented with the internal (e) and the external uncertainties (f).

evidenced from sediments collected in the eponym paleolake located in the higher Bolivian Altiplano (Placzek et al., 2006, 2013). The chronological framework deduced from UTh dating on carbonates indicates the Ouki deep lake cycle between 120 and $98 \mathrm{ka}$ (Placzek et al., 2006, 2013).

Steffen et al. (2010) already suggested a correlation between wet time intervals on the Altiplano and sediment aggradation in the Majes Valley. According to Steffen et al. (2010), the Acoy megafan recorded two phases of Rio Grande catchment development characterized by landsliding during the Ouki wet climatic event. The data from Steffen et al. (2010) indicate that during the megafan emplacement, between 112.0 and $96.7 \mathrm{ka}$, the Rio Grande permits the sediment transport and aggradation in the Acoy megafan downstream. Similar to the Lluta catchment in Chile, landsliding might have been initiated by enhanced precipitation and reduced friction along a basal shear plane due to increasing hydrostatic pressure in the groundwater (Hoke et al., 2004; Strasser and Schlunegger, 2005). The weighted average age of the last debris-flow deposit $(101.9 \pm 5.5 \mathrm{ka})$ also correlates with the Ouki event (120-98 ka). In the western Andes, other landslides have been associated with wetter climatic conditions such as the older Lluta collapse (northern Chile, $18^{\circ} \mathrm{S}$; Wörner et al., 2002), yielding a minimum age of $2.5 \mathrm{Ma}$ (Strasser and Schlunegger, 2005), the Tomasiri landslide (southern Peru, $17^{\circ} 30^{\prime} \mathrm{S}$ ), dated at $400 \mathrm{ka}$ (Blard et al., 2009) and younger landslides in Argentina, which have been associated with the Minchin wet event (40-25 ka; Trauth et al., 2003; Hermanns and Schellenberger, 2008).

We suggest that the Chuquibamba debris flow, which remobilized rotational landslide deposits, was triggered by an increase in pore-water pressure in the Huaylillas ignimbrite during the Ouki wet climatic event. After this event, none of the more recent wet climatic events identified on the Altiplano (e.g., Michin, 48-36 ka, and Tauca, 26-15 ka) triggered a large landslide or remobilized the Chuquibamba debris flow. Similarly, in Southern Peru, Keefer et al. (2003) identified only centimeter-scale debris flows for the last 

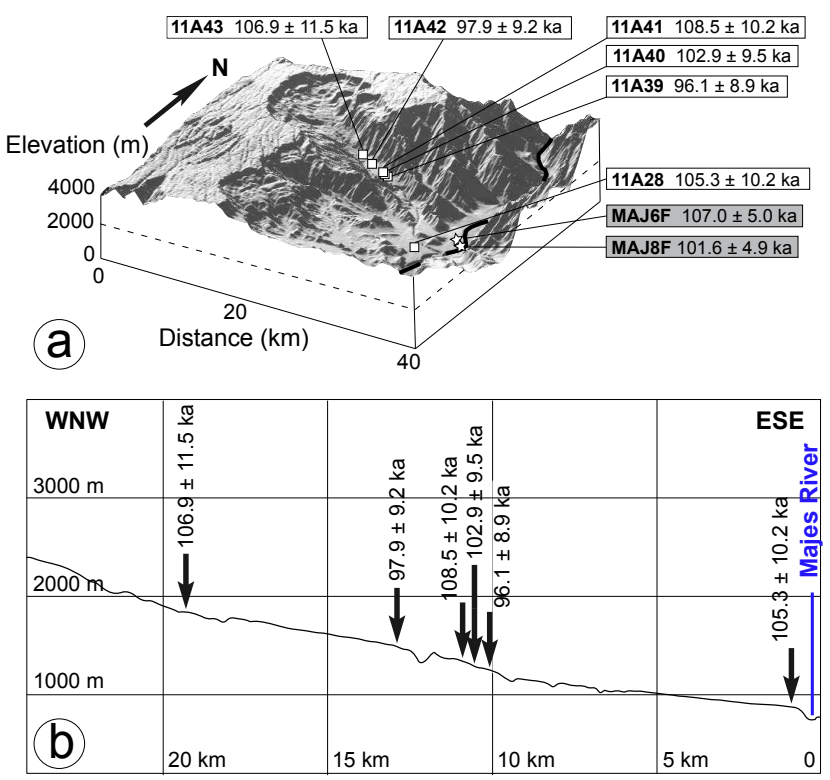

Figure 5. Samples location. (a) Digital elevation model (GeoMapApp, SRTM data, $90 \mathrm{~m}$ resolution) of the study area, showing samples location and TCN ages obtained for the debrisflow deposit and the Acoy megafan surface. OSL ages obtained by Steffen et al. (2010) for the Acoy megafan are noted in grey. (b) Elevation profile locating debris flow and the Acoy megafan ages.

38 kyr. These observations are consistent with the preservation of the Chuquibamba debris-flow morphology since its emplacement. We suggest that the Ouki event was the latest event whose duration and intensity was sufficient to trigger a large landslide in the arid western Andean flank (Wörner et al., 2002; Strasser and Schlunegger, 2005; Blard et al., 2009). Carretier et al. (2013) proposed that rare and strong erosive events contribute to more than $90 \%$ of the long-term erosion of the arid western side of the Andean range. Accordingly, we suggest that climatic fluctuations that favor landsliding, such as the Ouki wet event, have a great impact on sediment transport and morphologic evolution of the western flank of the Andes.

The important role of the tectonic framework on the localization and flow direction of mega-landslides has already been suggested for the Andean forearc domain (Pinto et al., 2008; Antinao and Gosse, 2009; Mather et al., 2014). As the Chuquibamba landslide is elongated in a NW-SE trend guided by the Incapuquio fault system, we suggest that the localization and geometry of the landslide is mainly controlled by preferential fracture orientations (Fig. 3b). More broadly, in southern Peru and northern Chile, most of the large landslides are located in tectonically fractured regions (Audin and Bechir, 2006; Pinto et al., 2008; Strasser and Schlunegger, 2005; Wörner et al., 2002; Crosta et al., 2015). This preferential localization suggests that tectonic fracturing plays an important role in preconditioning the landscape for landsliding within this arid area.
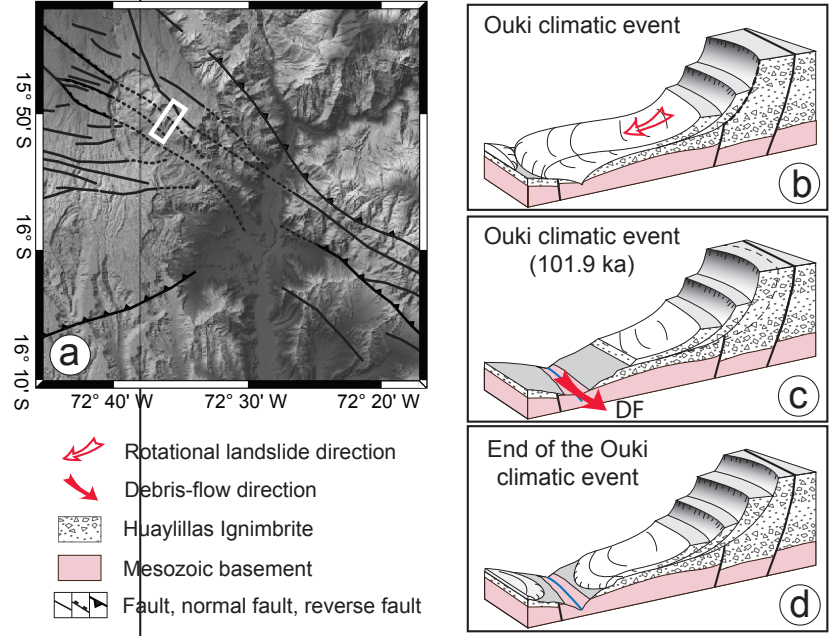

Figure 6. Map and block diagrams of the evolution of the Chuquibamba landslide. (a) SRTM numerical elevation model, the white rectangle localizes the block diagrams. (b) Block diagram showing rotational landslide initiation on the flank of the Chuquibamba Valley during the Ouki wet event. The landslide enlarges the valley and accumulates material at the bottom. (c) The accumulated materials are remobilized by debris flows during the wetter phases. (d) This remobilization allows new rotational landslides that enlarge the amphitheater-shaped valley.

No relationship between a $M_{\mathrm{w}} 8.0$ subduction earthquake and a giant landslide has been previously documented in southern Peru (Lacroix et al., 2013). However, Keefer et al. (2003) point out that a close temporal succession of subduction earthquakes and El Niño events produces debris flows in the coastal region (southern Peru). In our study area, even if the Ouki wet phase would favor triggering, we cannot exclude a contemporaneous seismic triggering event (subduction or crustal earthquake) for the Chuquibamba debris flows. More generally, robust arguments indicating such a correlation for giant landslides are scarce along the South American margin; other triggering factors (increase in pore pressure, climate change, glacial debuttressing) are usually invoked in addition to a seismic triggering event (Keefer, 2002; Pinto et al., 2008).

\subsection{Landscape evolution and tectono-climatic scenario}

We propose a landscape evolution scenario based on geomorphic marker analysis and new TCN ages (Fig. 6). The initial drainage network flowed toward the coast (i.e., in a southerly direction) and incised the roof of the weathered Huaylillas ignimbrite (Fig. 6a). These parallel incisions are still preserved (Fig. 3b, c) and sometimes even abandoned. Afterwards, the development of a graben structured by the Incapuquio fault system captured the drainage network along a $110^{\circ} \mathrm{N}$ trending direction (Fig. 3c), creating a new tributary of the Majes River. Rotational landslides were initiated by slope instabil- 
ity or pore pressure increase at the base of the Huaylillas ignimbrite during wet climatic events, as proposed by Hoke et al. (2004) and Strasser and Schlunegger (2005) for northern Chile (Fig. 6b). Sliding surfaces of rotational landslides are localized on fault planes and progressively enlarge the valley, as evidenced by the successive rotational landslide scarps (Fig. 3).

The rotational landslide deposits accumulated upstream in the valley (Fig. 6b) and were remobilized by debris flows during the Ouki event (120-98 ka; Fig. 6c). The accumulation of successive debris-flow and mudflow deposits at the outlet of the Rio Grande during the Ouki event formed the Acoy megafan (Steffen et al., 2010). Finally, at 101.9 $\pm 5.5 \mathrm{ka}$, the last major debris flow sealed the erosion/transport system (Fig. 6c). This pattern, with alternating upper slope destabilizations and sediment remobilization by debris flows, drove valley enlargement over time (Fig. 6d).

At the present time, the arid climate on the western flank of the Cordillera preserves geomorphologic features from erosion; the water yield comes only from rivers.

\section{Conclusions}

In this study we address how local tectonic activity and climatic fluctuations may control landslide occurrence at the arid western Andean front. Indeed, for the Chuquibamba landslide region, the sequence of debris flows (identified in the Acoy megafan stratigraphy and overlaying its roof) seems to have been favored by the occurrence of a wet climatic event (Ouki event), even if a contemporaneous seismic triggering event cannot be excluded. Our results suggest sediment accumulation in the valley during wet periods and incision during dry periods. Wet climatic events then appear to control the growth of the drainage network, participating in regressive erosion and in the creation of new tributaries on the western Andean front. Specifically, our results show that, during a wet event in a tectonically fractured region, hillslope processes, rather than fluvial erosion, dictate the evolution of the landscape at the channel head in the arid and high-relief area.

As rare and strong erosive events represent the most important contribution to the long-term erosion of the arid Western Cordillera (Carretier et al., 2013), we propose that events like the Chuquibamba landslide contribute significantly to the long-term erosion of the western escarpment of the Andes. We thus suggest a strong regional tectonic and climatic control of the long-term erosion of the arid western Andean front.

Acknowledgements. This project was supported by the Institut de Recherche pour le Développement (IRD). We acknowledge additional support from the Instituto Geologico Mineralogico y Metallurgico del Peru (INGEMMET, Peru). We thank all the staff from the ASTER AMS facility at CEREGE. We are grateful for detailed reviews from T. Schildgen and the anonymous reviewers, which helped to improve the manuscript. This work was carried out in the frame of the master's thesis of A. Margirier at ISTerre.

Edited by: V. Vanacker

\section{References}

Alpers, C. N. and Brimhall, G. H.: Middle Miocene climatic change in the Atacama Desert, northern Chile: Evidence from supergene mineralization at La Escondida, Geol. Soc. Am. Bull., 100, 1640-1656, 1988.

Antinao, J. L. and Gosse, J.: Large rockslides in the Southern Central Andes of Chile (32-34.5 $\mathrm{S})$ : tectonic control and significance for Quaternary landscape evolution, Geomorphology, 104, 117-133, 2009.

Atherton, M. P., Warden, V., and Sanderson, L. M.: The Mesozoic marginal basin of Central Peru: a geochemical study of withinplate-edge volcanism, in: Magmatism at a Plate Edge: the Peruvian Andes, edited by: Pitcher, M. P., Cobbing, E. J., and Beckinsale, R. D., Blackie Halsted Press, London, 47-58, 1985.

Audin, L. and Bechir, A.: Active Tectonics as Determinant Factor in Landslides Along the western Cordillera?, Congreso Peruano de Geologia, Lima, Peru, 17-20 October, 237-239, 2006.

Audin, L., David, C., Hall, S., Farber, D., and Hérail, G.: Geomorphic evidences of recent tectonic activity in the forearc, southern Peru, Special Volume on Neotectonics in South America, Revista de la Asociación Geológica Argentina, 61, 545-554, 2006.

Baker, P. A., Seltzer, G. O., Fritz, S. C., Dunbar, R. B., Grove, M. J., Tapia, P. M., Cross, S. L., Rowe, H. D., and Broda, J. P.: The history of South American tropical precipitation for the past 25,000 years, Science, 291, 640-643, 2001.

Balco, G., Stone, J. O., Lifton, N. A., and Dunai, T. J.: A complete and easily accessible means of calculating surface exposure ages or erosion rates from ${ }^{10} \mathrm{Be}$ and ${ }^{26} \mathrm{Al}$ measurements, Quat. Geochronol., 3, 174-195, 2008.

Bekaddour, T., Schlunegger, F., Vogel, H., Delunel, R., Norton, K. P., Akçar, N., and Kubik, P.: Paleo erosion rates and climate shifts recorded by Quaternary cut-and-fill sequences in the Pisco valley, central Peru, Earth Planet. Sc. Lett., 390, 103-115, 2014.

Blard, P. H., Lavé, J., Farley, K. A., Fornari, M., Jiménez, N., and Ramirez, V.: Late local glacial maximum in the Central Altiplano triggered by cold and locally-wet conditions during the paleolake Tauca episode (17-15 ka, Heinrich 1), Quaternary Sci. Rev., 28, 3414-3427, 2009.

Brown, E. T., Edmond, J. M., Raisbeck, G. M., Yiou, F., Kurz, M. D., and Brook, E. J.: Examination of surface exposure ages of Antartic moraines using in situ produced ${ }^{10} \mathrm{Be}$ and ${ }^{26} \mathrm{Al}$, Geochim. Cosmochim. Ac., 55, 2269-2283, 1991.

Carretier, S., Regard, V., Vassallo, R., Aguilar, G., Martinod, J., Riquelme, R., Pepin, E., Charrier, R., Hérail, G., Farias, M., Guyot, J. L., Vargas, G., and Lagane, C.: Slope and climate variability control of erosion in the Andes of central Chile, Geology, 41, 195-198, 2013.

Chmeleff, J., von Blanckenburg, F., Kossert, K., and Jacob, D.: Determination of the 10Be half-life by multicollector ICP-MS and liquid scintillation counting, Nucl. Instrum. Methods, 268, 192199, 2010. 
Cross, S. L., Baker, P. A., Seltzer, G. O., Fritz, S. C., and Dunbar, R. B.: Late Quaternary Climate and Hydrology of Tropical South America Inferred from an Isotopic and Chemical Model of Lake Titicaca, Bolivia and Peru, Quat. Res., 56, 1-9, 2001.

Devlin, S., Isacks, B. L., Pritchard, M. E., Barnhart, W. D., and Lohman, R. B.: Depths and focal mechanisms of crustal earthquakes in the central Andes determined from teleseismic waveform analysis and InSAR, Tectonics, 31, TC2002, doi:10.1029/2011TC002914, 2012.

Crosta, G. B., Paolo, F., Elena, V., and Hermanns, R. L.: The Cerro Caquilluco-Cerrillos Negros Giant Rock Avalanches (Tacna, Peru), Engineering Geology for Society and Territory, 2, 921924, doi:10.1007/978-3-319-09057-3_159, 2015.

Dunai, T. J., González López, G. A., and Juez-Larré, J.: OligoceneMiocene age of aridity in the Atacama Desert revealed by exposure dating of erosion-sensitive landforms, Geology, 33, 321324, 2005.

Grange, F., Hatzfeld, D., Cunningham, P., Molnar, P., Roecker, S. W., Suarez, G., Rodrigues, A., and Ocola, L.: Tectonic implications of the microearthquake seismicity and fault plane solutions in southern Peru, J. Geophys. Res., 89, 6139-6152, 1984.

Gunnell, Y., Thouret, J. C., Brichau, S., Carter, A., and Gallagher, K.: Low-temperature thermochronology in the Peruvian Central Andes: implications for long-term continental denudation, timing of plateau uplift, canyon incision and lithosphere dynamics, J. Geol. Soc. London, 167, 803-815, 2010.

Guzzetti, F., Mondini, A. C., Cardinali, M., Fiorucci, F., Santangelo, M., and Chang, K.-T.: Landslide inventory maps: new tools for an old problem, Earth-Sci. Rev., 112, 1-25, 2012.

Hall, S. R., Farber, D. L., Audin, L., Finkel, R. C., and Mériaux, A. S.: Geochronology of pediment surfaces in southern Peru: implications for Quaternary deformation of the Andean forearc, Tectonophysics, 459, 186-205, 2008.

Hall, S. R., Farber, D. L., Audin, L., and Finkel, R. C.: Recently active contractile deformation in the forearc of southern Peru, Earth Planet. Sc. Lett., 337-338, 85-92, 2012.

Hermanns, R. L. and Schellenberger, A.: Quaternary tephrochronology helps define conditioning factors and triggering mechanisms of rock avalanches in NW Argentina, Quatern. Int., 178, 261275, 2008.

Hoke, G. D., Isacks, B. L., Jordan, T. E., and Yu, J. S.: Groundwatersapping origin for the giant quebradas of northern Chile, Geology, 32, 605-608, 2004.

Hovius, N., Meunier, P., Ching-Weei, L., Hongey, C., Yue-Gau, C., Dadson, S., Ming-Jame, H., and Lines, M.: Prolonged seismically induced erosion and the mass balance of a large earthquake, Earth Planet. Sc. Lett., 304, 347-355, 2011.

Huaman, R.: Evolution tectonique Cenozoïque et néotectonique du piémont Pacifique dans la région d'Arequipa (Andes du Sud Pérou), PhD thesis, Université Paris Sud, Centre d'Orsay, 220 pp., 1985.

INGEMMET: Mapa Geológico del cuadrángulo de Caravelí, Ocoña, La Yesera, y Chuquibamba, scale 1:100 000, Lima, 2001.

Keefer, D. K.: Landslides caused by earthquakes, Geol. Soc. Am. Bull., 95, 406-421, 1984.
Keefer, D. K.: The importance of earthquake-induced landslides to long-term slope erosion and slope-failure hazards in seismically active regions, Geomorphology, 10, 265-284, 1994.

Keefer, D. K.: Investigating landslides caused by earthquakes - a historical review, Surv. Geophys., 23, 473-510, 2002.

Keefer, D. K. and Moseley, M. E.: Southern Peru desert shattered by the great 2001 earthquake: implications for paleoseismic and paleo-El Niño-Southern Oscillation records, P. Natl. Acad. Sci. USA, 101, 10878-10883, 2004.

Keefer, D. K., Moseley, M. E., and deFrance, S. D.: A 38000 year record of floods and debris flows in the Ilo region of southern Peru and its relation to El Niño events and great earthquakes, Palaeogeogr. Palaeocl., 194, 41-77, 2003.

Kelly, M. A., Lowell, T. V., Applegate, P. J., Phillips, F. M., Schaefer, J. M., Smith, C. A., Kim, H., Leonard, K. C., and Hudson, A. M.: A locally calibrated, late glacial ${ }^{10} \mathrm{Be}$ production rate from a low-latitude, high-altitude site in the Peruvian Andes, Quat. Geochronol., 26, 70-85, 2015.

Kober, F., Ivy-Ochs, S., Schlunegger, F., Baur, H., Kubik, P. W., and Wieler, R.: Denudation rates and a topography-driven rainfall threshold in northern Chile: multiple cosmogenic nuclide data and sediment yield budgets, Geomorphology, 83, 97-120, 2007.

Korschinek, G., Bergmaier, A., Faestermann, T., Gerstmann, U. C., Knie, K., Rugel, G., Wallner, A., Dillmann, I., Dollinger, G., Gostomski von C. L., Kossert, K., Maiti, M., Poutivtsev, M., and Remmert, A.: A new value for the half-life of ${ }^{10} \mathrm{Be}$ by heavy-ion elastic recoil detection and liquid scintillation counting, Nuclear Instum. Methods, 268, 187-191, 2010.

Korup, O., Clague, J. J., Hermanns, R. L., Hewitt, K., Strom, A. L., and Weidinger, J. T.: Giant landslides, topography, and erosion, Earth Planet. Sc. Lett., 261, 578-589, 2007.

Lacroix, P., Zavala, B., Berthier, E., and Audin, L.: Supervised method of landslide inventory using panchromatic SPOT5 images and application to the earthquake-triggered landslides of Pisco (Peru, 2007, $M_{\mathrm{W}} 8.0$ ), Remote Sensing, 5, 2590-2616, 2013.

Lal, D.: Cosmic ray labeling of erosion surfaces: in situ nuclide production rates and erosion models, Earth Planet. Sc. Lett., 104, 24-439, 1991.

Mather, A. E., Hartley, A. J., and Griffiths, J. S.: The giant landslides of northern Chile: tectonic and climate interactions on a classic convergent plate margin, Earth Planet. Sc. Lett., 388, 249-256, 2014.

McPhillips, D., Bierman, P. R., and Rood, D. H.: Millennial-scale record of landslides in the Andes consistent with earthquake trigger, Nat. Geosci., 7, 925-930, 2014.

Meunier, P., Hovius, N., and Haines, J. A.: Topographic site effects on the location of earthquake induced landslides, Earth Planet. Sc. Lett., 275, 221-232, 2008.

Merchel, S. and Herpers, U.: An update on radiochemical separation techniques for the determination of long-lived radionuclides via accelerator mass spectrometry, Radiochim. Acta, 84, 215-219, 1999.

Mortimer, C.: Drainage evolution of the Atacama Desert of northernmost Chile, Rev. Geol. Chile, 11, 3-28, 1980.

Perfettini, H., Avouac, J.-P., Tavera, H., Kositsky, A., Nocquet, J.M., Bondoux, F., Chlieh, M., Sladen, A., Audin, L., and Farber, D. L.: Seismic and aseismic slip on the central Peru megathrust, Nature, 465, 78-81, 2010. 
Pinto, L., Hérail, G., Sepúlveda, S. A., and Krop, P.: A neogene giant landslide in Tarapacá, northern Chile: a signal of instability of the westernmost Altiplano and palaeoseismicity effects, Geomorphology, 102, 532-541, 2008.

Placzek, C., Quade, J., and Patchett, P. J.: Geochronology and stratigraphy of late Pleistocene lake cycles on the southern Bolivian Altiplano: implications for causes of tropical climate change, Geol. Soc. Am. Bull., 118, 515-532, 2006.

Placzek, C. J., Quade, J., and Patchett, P. J.: A 130 ka reconstruction of rainfall on the Bolivian Altiplano: implications for the causes of tropical climate change, Earth Planet. Sc. Lett., 363, 97-108, 2013.

Rech, J. A., Currie, B. S., Michalski, G., and Cowan, A. M.: Neogene climate change and uplift in the Atacama Desert, Chile, Geology, 34, 761-764, 2006.

Roperch, P., Sempere, T., Macedo, O., Arriagada, C., Fornari, M., Tapia, C., Garcia, M., and Laj, C.: Counterclockwise rotation of late Eocene-Oligocene fore-arc deposits in southern Peru and its significance for oroclinal bending in the central Andes, Tectonics, 25, TC3010, doi:10.1029/2005TC001882, 2006.

Schildgen, T. F., Hodges, K. V., Whipple, K. X., Reiners, P. W., and Pringle, M. S.: Uplift of the western margin of the Andean plateau revealed from canyon incision history, southern Peru, Geology, 35, 523-526, 2007.

Schildgen, T. F., Hodges, K. V., Whipple, K. X., Pringle, M. S., van Soest, M., and Cornell, K.: Late Cenozoic structural and tectonic development of the western margin of the central Andean Plateau in southwest Peru, Tectonics, 28, TC4007, doi:10.1029/2008TC002403, 2009.

Sébrier, M., Mercier, J. L., Mégard, F., Laubacher, G., and CareyGailhardis, E.: Quaternary normal and reverse faulting and the state of stress in the central Andes of south Peru, Tectonics, 4, 739-780, 1985.

Sébrier M., Lavenu, A., Fornari, M., and Soulas, J. P.: Tectonics and uplift in Central Andes (Peru, Bolivia and Northern Chile) from Eocene to present, Géodynamique, 3, 85-106, 1988.
Steffen, D., Schlunegger, F., and Preusser, F.: Drainage basin response to climate change in the Pisco valley, Peru, Geology, 37, 491-494, 2009.

Steffen, D., Schlunegger, F., and Preusser, F.: Late Pleistocene fans and terraces in the Majes valley (southern Peru) and their relation to climatic variations, Int. J. Earth Sci., 99, 1975-1989, 2010.

Stone, J. O.: Air pressure and cosmogenic isotope production, J. Geophys. Res., 105, 23753-23759, 2000.

Strasser, M. and Schlunegger, F.: Erosional processes, topographic length-scales and geomorphic evolution in arid climatic environments: the "Lluta collapse," northern Chile, Int. J. Earth Sci., 94, 433-446, 2005.

Tavera, H., Audin, L., and Bernal, I.: Source parameters of Sama (Tacna) earthquake $\left(5.4 M_{\mathrm{W}}\right)$ of 20 November 2006, Bol. Soc. geol. Perù, 102, 109-115, 2007.

Thompson, L. G., Davis, M. E., Mosley-Thompson, E., Sowers, T. A., Henderson, K. A., Zagorodnov, V. S., Lin P. N., Mikhalenko V. N., Campen R. K., and Bolzan J. F.: A 25,000-year tropical climate history from Bolivian ice cores, Science, 282, 1858-1864, 1998.

Thompson, L. G., Mosley-Thompson, E., and Henderson, K. A.: Ice-core palaeoclimate records in tropical South America since the Last Glacial Maximum, J. Quat. Sci., 15, 377-394, 2000.

Thouret, J. C., Wörner, G., Gunnell, Y., Singer, B., Zhang, X., and Souriot, T.: Geochronologic and stratigraphic constraints on canyon incision and Miocene uplift of the Central Andes in Peru, Earth Planet. Sc. Lett., 263, 151-166, 2007.

Trauth, M. H., Bookhagen, B., Marwan, N., and Strecker, M. R.: Multiple landslide clusters record Quaternary climate changes in the northwestern Argentine Andes, Palaeogeogr. Palaeocl., 194, 109-121, 2003.

Victor, P., Oncken, O., and Glodny, J.: Uplift of the western Altiplano plateau: evidence from the Precordillera between 20 and $21^{\circ} \mathrm{S}$ (northern Chile), Tectonics, 23, TC4004, doi:10.1029/2003TC001519, 2004.

Wörner, G., Uhlig, D., Kohler, I., and Seyfried, H.: Evolution of the West Andean Escarpment at $18^{\circ} \mathrm{S}$ (N. Chile) during the last $25 \mathrm{Ma}$ : uplift, erosion and collapse through time, Tectonophysics, 345, 183-198, 2002. 